\title{
Total alimentary canal necrosis: infarction from oesophagus to anus
}

\author{
Mark McKelvie, 1,2 Dipankar Chattopadhyay²
}

'School of Clinical Medicine, University of Cambridge, Cambridge, UK

${ }^{2}$ Department of General Surgery, Bedford Hospital NHS Trust, Bedford, UK

\section{Correspondence to} Mark McKelvie, markmckelvie@gmail.com

Accepted 4 August 2017
CrossMark

\section{To cite: McKelvie $\mathrm{M}$}

Chattopadhyay D. BMJ Case Rep Published Online First: [please include Day Month Year]. doi:10.1136/bcr-2017 221957

\section{DESCRIPTION}

A middle-aged woman presented with a 12-hour history of generalised abdominal pain and septic. Her medical history included chronic alcoholism and a 40 pack-year smoking history. Laboratory tests revealed raised inflammatory markers and a macrocytosis. There were no liver, renal or clotting derangements, and haemoglobin and platelet levels were within normal limits. Blood gas analysis showed acidaemia and raised lactate. A CT scan of the abdomen revealed pneumoperitoneum, extensive portal venous gas and pneumatosis intestinalis throughout the entire imaged gut-from distal oesophagus all the way to anus-suggestive of complete intestinal necrosis (figures 1-3). The mesenteric arteries appeared patent. The patient rapidly deteriorated and died within 3 hours of admission.

Such CT appearances are in keeping with rare interlinked conditions adult necrotising enterocolitis and non-occlusive mesenteric ischaemia; however, such extensive necrosis of the entire intra-abdominal bowel has not been reported previously. Previous studies have hypothesised either a primary infective cause or a hypoxia-reperfusion injury from a primary vascular event leading to secondary infection from bacterial translocation across the injured bowel wall. ${ }^{1}$ Despite the unclear aetiology, a previous review of four cases describes common risk factors-chronic alcoholism and smoking-also present in this case. ${ }^{2}$

This case describes necrosis of the entire bowel with extensive portal venous gas and pneumoperitoneum-clearly incompatible with survival. Surgical options are limited. These appearances should be considered a preterminal sign and a high

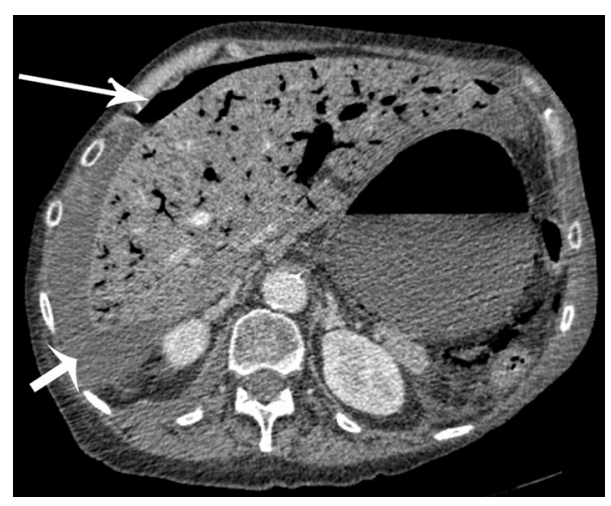

Figure 1 Axial CT image of upper abdomen showing extensive portal gas, pneumoperitoneum (long arrow) and intra-abdominal free fluid (short arrow). Gastric wall intramural gas (pneumatosis) is visible.

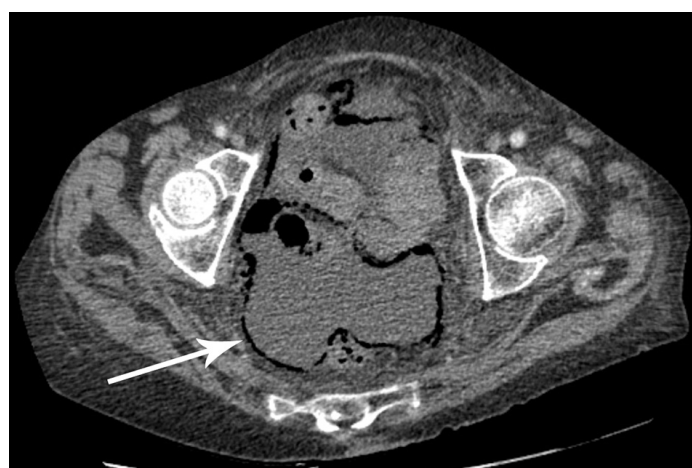

Figure 2 Axial CT image through pelvis showing significant intramural gas throughout the bowel loops (arrow).

index of suspicion for intestinal necrosis must be considered in alcoholics and smokers who present with an acute abdomen.

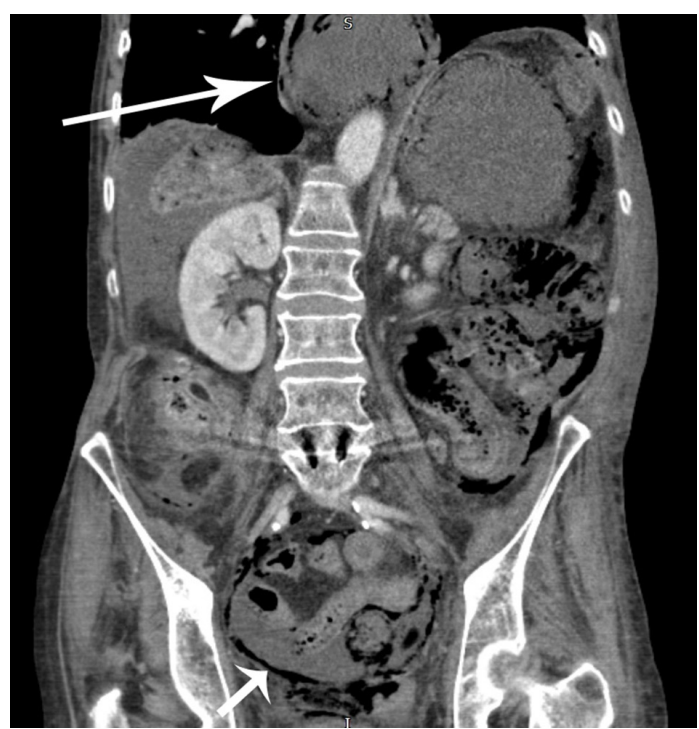

Figure 3 Coronal CT image demonstrating intramural gas in the oesophagus (long arrow). This is also present in the stomach, small and large bowel, including bowel in the pelvis (short arrow).

Learning points

- Extensive necrosis of the bowel with portal venous gas is usually considered a preterminal sign-surgical options are limited at this stage.

- A high index of suspicion for intestinal necrosis must be considered in alcoholics and smokers who present with an acute abdomen. 
Contributors MMcK: conception of the article, data collection, drafting the article and final approval of the version to be published. DC: critical revision of the article and final approval of the version to be published.

Competing interests None declared.

Patient consent Detail has been removed from this case description to ensure anonymity. The editors and reviewers have seen the detailed information available and are satisfied that the information backs up the case the authors are making.

Provenance and peer review Not commissioned; externally peer reviewed. (c) BMJ Publishing Group Ltd (unless otherwise stated in the text of the article) 2017. All rights reserved. No commercial use is permitted unless otherwise expressly granted.

\section{REFERENCES}

1 Reinus JF, Brandt LJ, Boley SJ. Ischemic diseases of the bowel. Gastroenterol Clin North Am 1990:19:319-43.

2 Zachariah SK. Adult necrotizing enterocolitis and non occlusive mesenteric ischemia. J Emerg Trauma Shock 2011;4:430-2.

Copyright 2017 BMJ Publishing Group. All rights reserved. For permission to reuse any of this content visit http://group.bmj.com/group/rights-licensing/permissions.

BMJ Case Report Fellows may re-use this article for personal use and teaching without any further permission.

Become a Fellow of BMJ Case Reports today and you can:

- Submit as many cases as you like

- Enjoy fast sympathetic peer review and rapid publication of accepted articles

Access all the published articles

Re-use any of the published material for personal use and teaching without further permission

For information on Institutional Fellowships contact consortiasales@bmjgroup.com

Visit casereports.bmj.com for more articles like this and to become a Fellow 